Archived version from NCDOCKS Institutional Repository http://libres.uncg.edu/ir/asu/

\title{
Appalachľan
}

B O O N E, N O R T H C A R O L I N A

\section{Transgender, Transsexual, And Gender Queer Individuals With A Christian Upbringing: The Process Of Resolving Conflict Between Gender Identity And Faith}

\author{
By: Denise L. Levy and Jessica R. Lo
}

\begin{abstract}
Individuals who identify as transgender, transsexual, or gender queer and Christian can face a unique set of challenges in attempting to integrate their faith and gender identity. The purpose of this qualitative study was to understand the process by which individuals with a Christian upbringing resolve conflict between their gender identity and religious beliefs. Analysis of interview transcripts revealed a model with the following fluid stages: experiencing gender socialization, having conflicts between views of self and socialized gender, defying gender norms, exploring gender and religious identities, and continually resolving issues as they arise. The article concludes with theoretical and practical implications.
\end{abstract}

Denise L. Levy PhD LCSW \& Jessica R. Lo MSW P-LCSW (2013). Transgender, Transsexual, and Gender Queer Individuals with a Christian Upbringing: The Process of Resolving Conflict Between Gender Identity and Faith, Journal of Religion \& Spirituality in Social Work: Social Thought, 32:1, 60-83, DOI:

10.1080/15426432.2013.749079. Publisher version of record available at: https://www.tandfonline.com/doi/ full/10.1080/15426432.2013.749079 


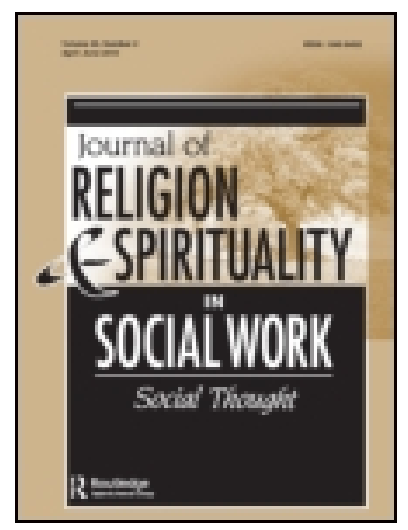

\title{
Journal of Religion \& Spirituality in Social Work: Social Thought
}

\section{Transgender, Transsexual, and Gender Queer Individuals with a Christian Upbringing: The Process of Resolving Conflict Between Gender Identity and Faith}

\author{
Denise L. Levy PhD LCSW ${ }^{a}$ \& Jessica R. Lo MSW P-LCSW ${ }^{b}$ \\ ${ }^{a}$ Department of Social Work, Appalachian State University, Boone, \\ North Carolina \\ ${ }^{\mathrm{b}}$ Caldwell County Department of Social Services, Lenoir, North \\ Carolina
}

To cite this article: Denise L. Levy PhD LCSW \& Jessica R. Lo MSW P-LCSW (2013): Transgender, Transsexual, and Gender Queer Individuals with a Christian Upbringing: The Process of Resolving Conflict Between Gender Identity and Faith, Journal of Religion \& Spirituality in Social Work: Social Thought, 32:1, 60-83

To link to this article: http://dx.doi.org/10.1080/15426432.2013.749079

\section{PLEASE SCROLL DOWN FOR ARTICLE}

Full terms and conditions of use: http://www.tandfonline.com/page/terms-and-conditions

This article may be used for research, teaching, and private study purposes. Any substantial or systematic reproduction, redistribution, reselling, loan, sub-licensing, systematic supply, or distribution in any form to anyone is expressly forbidden.

The publisher does not give any warranty express or implied or make any representation that the contents will be complete or accurate or up to date. The accuracy of any instructions, formulae, and drug doses should be independently verified with primary sources. The publisher shall not be liable for any loss, actions, claims, proceedings, demand, or costs or damages whatsoever or howsoever caused arising directly or indirectly in connection with or arising out of the use of this material. 


\title{
Transgender, Transsexual, and Gender Queer Individuals with a Christian Upbringing: The Process of Resolving Conflict Between Gender Identity and Faith
}

\author{
DENISE L. LEVY, PhD, LCSW \\ Department of Social Work, Appalachian State University, Boone, North Carolina \\ JESSICA R. LO, MSW, P-LCSW \\ Caldwell County Department of Social Services, Lenoir, North Carolina
}

\begin{abstract}
Individuals who identify as transgender, transsexual, or gender queer and Christian can face a unique set of challenges in attempting to integrate their faith and gender identity. The purpose of this qualitative study was to understand the process by which individuals with a Christian upbringing resolve conflict between their gender identity and religious beliefs. Analysis of interview transcripts revealed a model with the following fluid stages: experiencing gender socialization, having conflicts between views of self and socialized gender, defying gender norms, exploring gender and religious identities, and continually resolving issues as they arise. The article concludes with theoretical and practical implications.
\end{abstract}

KEYWORDS transgender, gender identity, Christian, identity, conflict

Spirituality and religion are key components in the lives of many people worldwide, and religious institutions often provide support to these individuals (Deutsch, Coleman, \& Marcus, 2006). In addition to being a source of

This research was supported in part by a summer research stipend through the College of Health Sciences at Appalachian State University.

Address correspondence to Denise L. Levy, PhD, LCSW, Assistant Professor, Appalachian State University, Department of Social Work, ASU Box 32155, Boone, NC 28608. E-mail: levydl@appstate.edu 
encouragement, faith can strongly shape an individual's identity and worldview. But what happens when there is conflict between one's religious beliefs and another aspect of identity? The conflict between Christianity and same-sex attraction has been well documented in popular media and scholarly writing (Buchanan, Dzelme, Harris, \& Hecker, 2001; Couch, Mulcare, Pitts, Smith, \& Mitchell, 2008; Donnelly, 2001; Levy, 2009; Rodriguez \& Ouellette, 2000). A more recent and less documented conflict is the tension between religious upbringing and gender identity (Kennedy, 2008; Kidd \& Witten, 2008; Stone, 2007; Wilcox, 2002).

Individuals who identify as transgender, transsexual, gender queer, gender nonconforming, or gender variant and Christian can face a unique set of challenges in attempting to integrate their faith and gender identity. "Expectations [based on gender] are usually predicated upon our genitalia and begin from the moment of birth, continuing throughout our lives" (Sheridan, 2001, p. 31). Many denominations cite Biblical notions of gender and gender roles to back up their strict views on gender. These include "So God created man in his own image, in the image of God he created him; male and female he created them" (Genesis 1:27) and "The woman shall not wear that which pertaineth unto a man, neither shall a man put on a woman's garment: for all that do so are an abomination unto the Lord thy God" (Deuteronomy 22:5).

Strict views of gender identity and gender roles based on the Christian faith do not always match up with the experiences of transgender individuals. Further, if they do not conform to gender expectations, they may face ridicule and rejection from their churches (Kennedy, 2008; Sheridan, 2001). Many transgender Christians, in turn, seek out an "individualized relationship with God" (Sheridan, 2001, p. 103), often facing "a period of denial and struggle" (Tanis, 2003, p. 38) as well as depression, disconnection, dissatisfaction, and spiritual difficulty before "discovering a sense of self that feels integral and true" (Tanis, 2003, p. 38). Even after discovering their gender identity, they may face barriers to participation in church activities. These include "fear and unfamiliarity on the part of the congregation, language issues, physical layout that separates people by gender, programs that exclude or separate by gender, pathologizing or designating trans issues as sinful, and overt hostility" (Tanis, 2003, p. 116). In addition to discrimination by faith groups, it is also noteworthy that some transgender individuals report experiences of "marginalization and denial ... from gay, lesbian, bisexual, and allied people and organizations" (Kujawa-Holbrook \& Montagno, 2009, p. 230).

Most studies related to this topic only include preliminary conclusions. Kidd and Witten (2008) explained that isolation from support networks such as religious groups can cause transgender individuals to struggle with spirituality and end-of-life issues. Wilcox's (2002) research included lesbian, gay, and bisexual communities as well as the transgender population. Participants 
reported having a more individualized faith rather than always conforming to institutional church doctrine. Coming from a different perspective, Kennedy (2008) explored churches' ideas on transgender members and proposed ways for churches to create balance between a literal interpretation of the Bible and compassion for this population. Similarly, Stone (2007) examined how church members can demonstrate love and tolerance for the transgender community by providing an environment of acceptance. Stone also provides advice for pastors on how to overcome resistance and fear from congregations. Across these studies and texts, authors explain that Christian churches need to make concrete decisions about their views on transgender members.

Although this information is helpful, there is still a significant gap in the scholarly literature concerning the resolution of conflict between gender identity and Christian upbringing for transgender individuals. The literature tends to examine perspectives of the religious institutions (Kolakowski, 1997; Watts, 2002) rather than including the voices of those who have experienced conflict between gender identity and religious beliefs.

In addition to the scholarly literature, there are several publications related to this topic, mostly from online magazines and theological or pastoral care texts (Kujawa-Holbrook \& Montagno, 2009; Lewis, 2009; Sheridan, 2001; Tanis, 2003). Lewis (2009), for instance, reports that:

Just about everyone who is transgender has a similar story about an awkward conversation, a sense of disapproval, the cold shoulder, or a little reference to hell. Many transgender people end up leaving these churches, their families, and their expectations. (A False Dichotomy Section, ๆ 7)

Lewis goes on to say that even though some churches are accepting of transgender members and clergy, most mainline denominations are not, a trend which will likely continue for some time.

In order to benefit researchers, practitioners, and society at large, this study addressed a gap in the literature by describing the conflict between gender identity and Christian upbringing using participants' own words. The purpose of this study was to understand the process by which individuals with Christian upbringing resolve conflict between their gender identity and religious beliefs. Within this broad purpose there were four research questions. First, how do participants define the conflict between their gender identity and religious beliefs? Second, what personal and contextual factors shaped their efforts to resolve this conflict? Third, what is the process by which individuals resolve this conflict? Finally, how do participants describe their resolution of this conflict? 


\section{CONCEPTUAL FRAMEWORK}

Several theories and concepts informed this research, including gender identity development, faith development, postmodern identity perspectives, and queer theory. These are briefly outlined below. However, in order to discuss these theories, it is important to first present the terms and definitions associated with this topic, including biological sex, gender, gender roles, gender identity, transgender, transsexual, gender nonconforming and gender queer. All of these terms are defined below and are related to gender. Gender identity is distinct from sexual orientation, which has to do with attraction.

Biological sex and gender may be critical components of a person's overall identity. Historically, scientists defined two sexes, male and female (Burdge, 2007), and genetically distinguished these categories by their chromosomal differences XY and XX. Biological sex includes physical attributes such as sex chromosomes, gonads, hormones, and reproductive structures (American Psychological Association, 2006). Conversely, the term gender is often used to describe the ways people conceive of themselves based on society's construction of gender, gender roles, and gender expression (Rudacille, 2005). Social constructs often reinforce a binary gender system and label certain activities as masculine or feminine. Although society has started to become more accepting of fluid gender roles, many continue to believe in the binary system of gender roles, appearances, and identity (Rudacille, 2005). According to Rudacille (2005), this binary consists of traditional feminine roles which may include domestic tasks, nurturing and caring for the family, and vulnerability; and masculine roles which may include being the primary wage earner, being less emotionally invested in family life, and completing household tasks requiring more strength. Finally, how people define themselves with respect to gender is known as gender identity, which may or may not fall within the binary system (Rudacille, 2005). Examples of gender identity include male, female, transgender, transsexual, gender queer, cisgender, gender nonconforming, and so forth.

Transgender individuals often experience conflict between their physical body and their cognitive experiences of gender, perhaps because of the separate prenatal development of the genitalia in the first 2 months of pregnancy and sexual differentiation in the brain in the second half of pregnancy (Swaab, 2007). An individual, for example, who was born as a female may overwhelmingly feel like a male. This can lead to difficulties when people are totally repulsed by their biological sex, which is the main criteria for Gender Identity Disorder recognized by The Diagnostic and Statistical Manual of Mental Disorders (DSM-IV-TR) (American Psychiatric Association, 2000). It is important to note that the inclusion of Gender Identity Disorder in the DSMIV-TR is controversial, with some mental health practitioners and transgender individuals believing that the criteria do not indicate an actual mental disorder (Denny, Green, \& Cole, 2007). Further, a large majority of the transgender 
population does not feel the intense disgust necessary for this diagnosis; they simply have a pervasive feeling that they are in a misplaced body (American Psychiatric Association, 2000). It is important to know that the transgender population is not a homogenous one and that there are numerous variations in the types of individuals who identify within this umbrella term.

Only a small number of transgender individuals also identify as transsexual (Denny et al., 2007). Although transgender individuals may wear gender-neutral clothing and typically do not seek sex reassignment surgery, transsexuals have a definite sense of themselves as belonging to the nonnatal sex and often live as the "other" sex (Denny et al., 2007). Transsexuals may pursue sex reassignment surgery, cosmetic surgery, hormone replacement, live as the "opposite" sex without surgery, or internalize and hide their struggles (Kennedy, 2008).

Those who identify more generally as gender nonconforming or gender variant are simply individuals who refuse to accept the gender roles society has prescribed to them (Gherovici, 2010). Gender queer, a previously derogatory term which has been reclaimed by many people, is used to indicate an "identity without an essence" (Halperin, 1995, p. 65). However, this term goes beyond the notion of gender nonconformity by its political nature and uncertain definition as discussed further below.

\section{Gender Identity Development}

According to Ross-Gordon (1999), gender identity can be developed through gender socialization, imitation, reinforcement, and vicarious learning. In other words, children form gender identity by observing accepted gender roles, behaviors, and dress in their homes, communities, and the media. Ross-Gordon goes on to say that children are further influenced by cultural factors such as the parent-child relationship, school environment, and stereotypes. Typically, children will initially conform to expectations based on biological sex, though they may deviate from their socialized gender as they age.

Looking to transgender identity development, Morgan and Stevens' (2008) study with female-to-male transgender adults found four themes in the narratives of participants. These were: early experiences of dissonance between the body and mind, biding time until transition opportunities arose, missing potential opportunities for transition, and physically transitioning into the preferred gender. Based on research and personal experience, Devor's (2004) 14-stage model of transsexual identity formation includes: abiding anxiety, identity confusion about originally assigned gender and sex, identity comparisons about originally assigned gender and sex, discovery of transsexualism, identity confusion about transsexualism, identity comparisons about transsexualism, tolerance of transsexual identity, delay before acceptance of transsexual identity, acceptance of transsexual identity, 
delay before transition, transition, acceptance of posttransition gender and sex identities, integration, and pride. Whether considering transgender or transsexual identity development, many argue for "broader, more flexible models of gender identity development" that are not necessarily linear paths leading to one possible outcome for the entire population (Schwartz, Luyckx, \& Vignoles, 2011, p. 629).

Although not a linear model of identity development, Tanis (2003) presents common experiences of children and adolescents related to transgender identity development. According to Tanis, children often feel that they have to keep their longings secret, which can be traumatizing and isolating. Further, they are "subject to taunting, harassment, and even violence in the school and on the playground" (Tanis, 2003, p. 27). In beginning to define themselves and their identities, "transgender adolescents face additional challenges, including the all-too-frequent occurrence of violence and rejection at home, school, and church" (Tanis, 2003, p. 34). Additionally, transgender adolescents are forced to confront physical changes that occur with puberty. Transgender individuals of all ages may experience depression, disconnection, dissatisfaction, and spiritual difficulty.

\section{Faith Development}

This study included a focus on faith and religious identity development based on Fowler's (1981) stages of faith. Believing that faith progresses much like other aspects of identity and human development, Fowler based his stages on interviews with 350 individuals as well as developmental theories of Kohlberg, Erikson, and Piaget. Faith, in Fowler's theory, is "loyalty to a transcendent center of value and power" (p. 14); it is "an orientation of the total person, giving purpose and goal to one's hopes and strivings, thoughts and actions" (p. 14). Fowler identified progressive periods of faith that people experience, and his linear conceptualization included six such periods: intuitive-projective, mythic-literal, synthetic-conventional, individuative-reflective, conjunctive, and universalizing faith.

\section{Postmodern Identity Perspectives and Queer Theory}

In taking a postmodern view of identity, the concepts of gender identity and religious upbringing can be examined with an eye for fluidity, flexibility, and plurality (Schwartz et al., 2011). From this perspective, the self is regarded as multifaceted, changing, and dynamic (Levy, 2009). Coady (2001) explained the difference between a postmodern and modern view of the world:

Postmodern philosophy challenges the modernist viewpoint that truth can be discovered via objective scientific observation and measurement. As opposed to the modernist quest to discover universal principles and 
large-scale theories that underlie all human behavior, the postmodernist holds that there is no absolute truth, only points of view. (p. 37)

Essentially, postmodernists view truths as multiple and relative instead of searching for an all-encompassing Truth that applies to all people and situations (Applegate, 2000).

In addition to the postmodern identity perspective, queer theory provides a lens through which one can examine faith and gender identity as fluid and intertwined concepts. Previously used as a derogatory term, queer has recently been reclaimed by those who resist a dichotomous view of gender and sexuality. Incorporating a nuanced meaning, queer is considered "sometimes as an umbrella term for a coalition of culturally marginal sexual self-identifications and at other times to describe a nascent theoretical model which has developed out of more traditional lesbian and gay studies" (Jagose, 1996, p. 1). Influenced by Foucault, Sedgwick, Butler, Derrida, and others, queer theory places value in unconventional or nonnormative genders and sexualities and characterizes identity as a cultural construction (Talburt \& Steinberg, 2000). Both of these theories are particularly relevant to this study, which seeks to illuminate the experiences of transgender, transsexual, and gender queer individuals with a Christian upbringing.

\section{METHODOLOGY}

Qualitative research is often employed to study complex problems, to develop new theories, and to understand context (Creswell, 2007). This study utilized grounded theory, a type of qualitative research that leads to a theory grounded in the data (Creswell, 2007; Glaser, 2007). Grounded theory includes simultaneously collecting and analyzing data, generating codes and categories from the data, constantly comparing data, and constructing a theory based on the data (Charmaz, 2006).

Although grounded theory studies may have large sample sizes, Creswell's (2007) text presents an exemplary study completed with 11 participants. Due to recruitment constraints mentioned below and beginning saturation of data, this study included in-depth interviews with five participants who were selected using maximum variation sampling. We began the study by purposefully selecting diverse participants based on type or denomination of Christian upbringing or gender identification. Participants were recruited via flyers posted to listserves, support groups, and advocacy groups relevant to the transgender community. A very brief prescreening was held over the phone to ensure interested individuals met the study's criteria, which included: being at least 18 years old; living within the designated research area; identifying as transgender, transsexual, intersex, gender queer, gender variant, or gender nonconforming; having a Christian upbringing; 
TABLE 1 Participants' Demographic Information

\begin{tabular}{|c|c|c|c|c|c|c|c|}
\hline $\begin{array}{l}\text { Fake } \\
\text { Name }\end{array}$ & Age & Race & $\begin{array}{l}\text { Bio } \\
\text { Sex }\end{array}$ & $\begin{array}{l}\text { Gender } \\
\text { Identity }\end{array}$ & $\begin{array}{l}\text { Highest } \\
\text { Degree }\end{array}$ & $\begin{array}{l}\text { Religious } \\
\text { Upbringing }\end{array}$ & Current Religion \\
\hline Alex & 18 & White & $\mathrm{F}$ & Transgender & HS & $\begin{array}{l}\text { Church of } \\
\text { Christ }\end{array}$ & Church of Christ \\
\hline Steve & 28 & White & M & Transgender & HS & $\begin{array}{l}\text { Presbyterian } \\
\text { and Baptist }\end{array}$ & Christian \\
\hline Peter & 44 & White & M & $\begin{array}{l}\text { Gender } \\
\text { Queer }\end{array}$ & $\mathrm{PhD}$ & $\begin{array}{l}\text { Presbyterian } \\
\text { and Baptist }\end{array}$ & $\begin{array}{l}\text { Nondenominational } \\
\text { Christian }\end{array}$ \\
\hline Jessie & 53 & White & M & Transgender & JD & Catholic & Catholic \\
\hline Amy & 44 & White & M & Transsexual & MS & Methodist & $\begin{array}{l}\text { Agnostic and } \\
\text { Christian }\end{array}$ \\
\hline
\end{tabular}

and having experienced and addressed conflict between religious beliefs and gender identity. Recruitment proved difficult in the primary research area, which was located in rural Appalachia; thus the recruitment area was expanded to include two cities located in the Southeastern United States.

Table 1 provides demographic information about these participants, including pseudonyms, and is presented in the order in which they were interviewed. Throughout the article, participants are described using pronouns that they identified as preferable. Overall, the sample was diverse in terms of age, educational attainment, gender identification, denominational background, and current faith identification. Additionally, participants varied in the length of time that they personally identified with their current gender identity, from about 1 year to over 20 years. Though not racially diverse, the participants of the study are representative of the primary region in which the research occurred. According to the United States Census Bureau (2010), the area in which the research was based, located in rural Appalachia, was approximately 95\% Caucasian. A majority of participants were from this area.

Respondents participated in semistructured interviews lasting from 30 to 100 min that were conducted over an 8-month period. Interviews took place in a university office, in a participant's office, and in a participant's home. They were audio taped and transcribed verbatim, and transcripts were coded using grounded theory methods of open, focused, and axial coding. In addition to coding by hand, analysis was also completed using ATLASti. In particular, this study adhered to Charmaz's (2006) constructivist grounded theory, recognizing that data and analysis should be understood in the context of time, place, situation, and culture.

In qualitative research, reliability and validity are synonymous with the concept of trustworthiness (Merriam, 2009). This study utilized the following techniques to ensure rigor: triangulation, peer examinations, member checks, rich description, and maximum-variation sampling (Bogdan \& Biklen, 2007; Maxwell, 2005; Merriam, 2009). However, as with all studies, there were 
limitations. Limitations included the lack of racial diversity in the sample, possible regional differences for participants from the Appalachian area (Eldridge, Mack, \& Swank, 2006; Swartz, 2003), and the small sample size.

\section{RESULTS}

In keeping with the methodology of grounded theory, a "substantive level theory that is written by the researcher that addresses a specific problem or population of people" was developed based on interview data (Creswell, 2007, p. 67). Data analysis revealed five fluid stages experienced by participants as they resolved conflict between their Christian upbringing and gender identity (See Figure 1). These five stages are: experiencing gender socialization, having conflicts between views of self and socialized gender, defying gender norms, exploring gender and religious identities, and continually resolving issues as they arise. Participants did not necessarily experience each of these stages in a linear fashion, and the model is intended to be fluid.

\section{Experiencing Gender Socialization}

Participants spoke at length about how they were socialized by their families, communities, and churches to behave in a way consistent with societal norms for their biological sex.

\section{FAMILY}

The process of gender socialization began at home for most participants. As children they were coached on how to dress or act. One participant, Alex, shared her experience of being forced to dress a certain way by her father:

\footnotetext{
Sunday mornings he would make us dress up in jumpers or Easter dresses and hose. We wore pink panty hose with the little dolly, black, shiny buckle shoes and he would comb my hair for 30 minutes and make sure it was parted down the middle and that it was perfectly straight.
}

Regarding interests and behaviors, Peter explained that he was "expected to do things like play soccer and little league." Instead, he "spent the time in the outfield making little piles of dirt" because he "really didn't care" about sports. Experiences such as this were often a point of stress and conflict within participants' relationships with their parents. One exception is Jessie, who explained that she "was not raised with any gender roles" and that her 
Family

\section{Experiencing Gender Socialization}

- Acceptable clothing and behaviors

- Limited connection or understanding

- Community
- Strict gender roles

- Church

- Messages about sexuality and gender

○ Observable gender roles

\section{Having Conflicts Between Views of Self and Socialized Gender}

- Dreaming about being the "other gender"

- Trying to fit in

- Experiencing isolation and depression

\section{Defying Gender Norms}

- Choosing clothes

- Choosing toys

- Performing

\section{Exploring Gender and Religious Identities}

- Doing research

- Talking to others

o Family

- Community

- Church

- Forming new identities

\section{Continually Resolving}

- Gender identity

○ Still forming

- Becoming comfortable with self

- Religious identity

- Maintaining core beliefs

- Personalizing faith

- Not regularly attending church

FIGURE 1 Five fluid stages of resolving conflict.

mother encouraged her to cook, take ballet classes, and do whatever else interested her.

In addition to prescriptions regarding the way that they behaved and dressed, participants indicated that they had a limited connection or understanding with their parents during this time of gender socialization. For instance, Steve had "no relationship" with his dad. He explained:

He had no way of understanding me and the only thing he really understood was sports. I had no desire for any of that kind of stuff. So we had 
no relationship at all. He was not a touchy feely person and his whole side of the family is very, very emotionless and reserved and pretty quiet.

\section{COMMUNiTY}

In addition to family expectations, participants identified standards regarding what was acceptable within their communities. The majority of the gender socialization that participants experienced in their communities took place within their schools, where they found strict understandings of gender roles. Steve discussed how his school had very strict dress codes based on gender: "We had to wear jeans or dress pants every single day with a collared shirt and belt. Girls had to wear dresses or a blouse and a skirt." He went on to say:

Gender roles were so incredibly strict. The stuff that they teach you and the stuff that you learn and the stuff that you're supposed to do are forced on you so hard that it's really kind of oppressive and it was very hard to see myself. There was no room to evaluate yourself there was not any room to think about who you were or who you wanted to be and there was no room for exploration and all.

Similarly, Jessie had a difficult time connecting with her peers at school because they didn't seem to understand her interest in ballet and literature.

\section{CHURCH}

Participants noted that their churches often discussed issues pertaining to sexual orientation and homosexuality; yet gender identity was never discussed. For instance, Amy explained that gender identity "wasn't on the radar" and that instead the message was that "homosexuality is bad." Although not discussed overtly, some participants did observe certain roles and responsibilities held by members of the church based on gender. Typically male members of the church held more administrative roles and positions of power such as deacons and priests. Overall, participants expressed unclear messages about gender and gender identity from their church and explained that the focus was often on other issues such as sexual orientation and abortion.

\section{Having Conflicts Between Views of Self and Socialized Gender}

All of the participants discussed their experiences of conflict between the way they viewed themselves and the way they had been socialized related to gender. In particular, they mentioned dreaming about being the "other" gender, trying to fit in, and experiencing isolation and depression. 


\section{Dreaming About Being the "Other" Gender}

In her regular "fantasies about being male," Alex explained, "I dreamt that I was cross-dressing and I used the men's room." However, she went on to say: "Whenever I had a dream about being a boy, I would subconsciously dismiss it and I would wake up saying 'oh that was an excellent dream' and then go on with my day." For Steve, these dreams took the form of thinking about having longer hair. Jessie recounted dreaming at age 12 that she "would wake up in the morning and be completely female with a wonderful voice" and often prayed that this would happen.

\section{TRYING TO FIT IN}

In addition to dreams, participants were often preoccupied with a struggle to fit in. For instance, in talking about his Fundamentalist Baptist school, Steve said:

The school was very, very extreme about all these sorts of things. I can really think about times when I unknowingly pushed the line I guess. To a large extent I really wanted to try and fit in there because it was where I was. It was my life. For those thirteen years, I was to be in that school. I couldn't really escape it and so, to some extent, I needed to fit in.

Amy explained that she spent 10 years "suppressing" her gender identity and "trying not to be trans." Similarly, Jessie explained that "a large chuck of me was in the closet, and it was getting worse. The closet was getting more cluttered and I was coming apart. It was becoming harder to control." Even though it was difficult, Jessie still felt the need to be a "chameleon" and became adept at rationalization and "re-crafting things."

\section{EXPERIENCING ISOLATION AND DEPRESSION}

Having conflict between their socialized gender and their views of themselves often resulted in a sense of isolation and depression in the participants. Regarding isolation, Alex explained that she "was always an outcast" and "never really had a lot of close friends." Similarly, Steve confessed: "A lot of times I had to play by myself and I wanted to because I didn't want to be around some of the people who didn't really like me and didn't understand me." He went on to say:

I didn't have very many friends and I was a single child and I had one friend in the neighborhood. I only had one friend in the entire history of 
me being in that school that ever came to the house and that was only twice, so I really didn't have anybody to hang out with.

Steve talked at length about how his sense of isolation and confusion led him into a deep depression that lasted for several years. He said, "I was going through so much depression because there were all these things going on and all this pressure to conform." Amy, whose prayers to "get rid of" her trans identity did not work, experienced "a lot of guilt." Like the other participants, Amy also mentioned depression and said that she initially expected that she would probably be dead by now. Regarding her emotional state, Jessie said:

Somewhere around age seven I started crying inside and that never stopped. I had this incredible, incredible pain, and it was psychic pain, and I never knew what the problem was ... Also, growing up without a peer support network conditioned me to follow my drummer. It's been very lonely following that drummer. It really has. But you've got to.

\section{Defying Gender Norms}

Although they still experienced conflict between their own views of themselves and socialized gender, participants slowly began defying gender norms in their behaviors rather than vicariously through their dreams. This defiance occurred through choosing toys, choosing clothes, and performing in ways that were congruent with their views of themselves.

\section{ChoOsing TOYs}

Defying the gender norms was a very fluid process that took place over many years and often began in early childhood. Steve, for example, remembered back to sometime early in grade school when he played with the girls' dolls at his day care program. He recalled:

I was just playing with the girls with their toys, and someone came over and stopped me. "No, you have to go over here and play with that stuff." And I remember asking "why, what's the big deal?" They said, "You just have to; this is what you're supposed to do." I wasn't going to fight it or anything. I was never really one of those kids to try and fight the system, but little things like that kept happening.

Peter's experience was in a Baptist Sunday School class in which the room "was divided with boy toys on one side and girl toys on the other." He also remembered the situation well: 
I was playing over in the play kitchen and the teacher pulled my mother aside and said that she was concerned. From that point on I wasn't allowed to play on the girls' side. I could only play on the boys' side. I didn't understand and I didn't know why I was not allowed to play over there.

Jessie discussed being a "boy's boy" in some instances and defying gender norms in other instances, such as taking ballet lessons, picking dried flowers, enjoying literature and poetry, and being miserable at sports. She explained, "I was doomed from the start ... I didn't fit their mold ... I was always more interested in scones than scores."

\title{
Choosing Clothes
}

For Alex, choosing clothes started in her dreams but then progressed to real life. She explained:

\begin{abstract}
Every single time I had an excuse to dress up, I would. Like during spirit week there would be opposite day or something like that and I would dress as a guy. Or I dressed up in guys' costumes and my excuse would be that girls' costumes are skanky or uncomfortable. So I felt good about having an excuse, but I never really thought about it twice. I was like, "I want to be a guy today so I'm going to use this as an excuse."
\end{abstract}

Unlike Alex, Steve's behavior occurred behind closed doors. He acknowledged: "I've bought myself clothes that I like every now and then, and I've bought myself skirts. But I hide them I don't let anybody see them so it's not really being open."

\section{PERFORMING}

The greatest sense of satisfaction that was described in regard to gender roles was when there was a safe way for participants to behave or perform in a way that corresponded with their desires. Steve would "play pretend" and "would volunteer to be girl characters." In describing the experience, he noted, "It was fun ... and maybe it was more natural than I realized." As he got older and technology flourished, Steve found comfort in playing games with people online and picking "girl characters" while still being himself. Because people assumed he was a girl, he found "room to explore myself more" in the virtual world. Similarly, Jessie "picked female" as her avatar while playing an online game and this was the first image of herself that she "emotionally owned." For Peter, gender rules were meant to be broken. $\mathrm{He}$ elaborated: 
Gender wise, I've always liked cooking and I still love cooking. To me it wasn't a gender thing; it was something I was interested in. Very early on, I didn't really buy into the gender rules. Apparently my penmanship was too feminine. I was told by many classmates that I carried my books wrong; I carried them like a girl. But once I started hearing gender comments, that I wasn't fulfilling my masculine roll, I didn't really understand the reasoning behind it. So, screw it. I'm going to do what I want to do. So I've been pretty gender neutral my whole life. I mean, I do feminine things and I do masculine things. I wear flannel and I chop wood and I polish crystal. I deal in antiques and vintage clothing . . . I'm more gender neutral.

\section{Exploring Gender and Religious Identities}

Almost simultaneously with defying gender norms, participants began the process of exploring their gender and religious identities. This process included doing research, talking to others, and forming new identities.

\section{DOING RESEARCH}

Doing research was highly beneficial to participants during this process, with the internet proving to be especially helpful. Alex shared that she frequently used online forums to explore being transgender and her complex emotions and thoughts about that notion. She stated:

I started doing my own research and then I talked to a couple of my friends and I found out that they were transgender, and they helped introduce me to all of the culture and terms and things to help figure me out the big question mark that is me.

Amy explained that doing research was helpful because it not only provided her with more information, but it also assisted in connecting her to other trans people. Also, researching her religious identity, she took courses in college, such as Introduction to the Old Testament and Current Religions, and "read voluminously." Similarly, Jessie describes reading many Catholic texts and historical Christian writings and becoming well-versed in the history and traditions of Catholicism. In particular, Jessie has explored Catholic teaching on morality and on "transgenderism."

\section{TALKING TO OTHERS}

In addition to exploring and researching information online, talking with others was a part of the exploration process for many participants. Some of 
these conversations were support and others were rejecting. Alex said about her mom:

I talked to her about cross-dressing, and as soon as I said that, there was a little bit of silence. But she accepted it and I was really, really, really happy because she went so far as to say "I'm going to talk to oncologist before you start binding [her breasts] because breast cancer runs in our family like crazy." I was really happy to hear that she was supportive in that way to go out of her way to make sure I was safe.

Alex's sister, on the other hand, was not surprised by Alex's announcement and was actually expecting her to share her identity questions because she would often "wear certain clothes and act in a certain way."

Not all participants received support from their family members. For instance, although Peter's family has been mostly tolerant, he describes one of his sister's as "very fundamentalist" and someone sees everything as "black and white, right or wrong, and the fuzzy edges are not of God." Peter explained, "I go there and I visit them, we hang out, and I run errands, but we don't talk about the white elephant." Because of concerns about being rejected, Steve has only shared his gender identity with one family member (his mom) who, in turn, made such comments as "maybe it's the Devil trying to lead you out of church" and "you're compensating for the fact that your penis is small." Regarding his Dad and paternal relatives, Steve explained:

I don't know how I would tell them, or if I could tell them. Sometimes I feel like moving somewhere where I don't even have to interact with them anymore and just live my life and not even bother to tell them.

Similarly, Amy's parents "rejected" her gender identity "because they think it's wrong" and that it's a "personal weakness." She states that her parents have developed these views based on their religious beliefs, and that she actually has not seen her parents in over five years because of the tension between them. Her husband, however, who has been with her since 2004 when she began living as a female, has been very supportive. Finally, Jessie is out to her immediate family members, her wife and two sons, as well as some of her extended family members. She is temporarily separated from her wife now, and one of her sons said that if she goes through sex reassignment surgery, then he will cut his ties with her. Overall, Jessie describes her relationship with her family as transitioning and unclear.

In addition to family members, some participants discussed their experiences with community members, and were especially assisted by support groups set up for transgender individuals. For instance, Amy explained that her support group has provided comfort to her when she had nowhere else 
to turn. Jessie has also attended several support groups, but she has found these only somewhat helpful.

Finally, many participants spoke with church members and leaders. Alex, for instance, spoke with her new preacher and opened up about who she is. She describes her take on the interaction: "I got the feeling that he thought I was going through a phase." Alex believes that most of her church members would think she was going through a phase. Additionally, "the older people would be a lot more conservative so they might be a little more upset and aggressive, but not in a dangerous way." Jessie spoke with a priest and even went to a few meetings of Sexaholics Anonymous to please him, but is not out to most of the people in her old faith communities.

\section{FORMING NEW IDENTITIES}

The end result of the cumulative research efforts and conversations with others was the beginning stage of forming of new religious and gender identities. Alex explained the questioning and answering that happened at the beginning of this formation:

I started questioning what role I am supposed to play and if I should do something (surgery, cross-dress) or not because I'm not exactly on one end or the other (of gender expression). I have to figure out what is appropriate for me.

Amy explained that her explorations forced her to reconsider her conceptualization of both religion and gender. Jessie also explored and questioned her faith, and tried a bit of everything, including New Age religions, psychedelic drugs, meditation, Judaism, Neo-Paganism/Wicca, and traditional Catholicism.

\section{Continually Resolving}

In the final piece of participants' journeys, they discuss the continual resolution that occurs when managing conflict between gender identity and religious upbringing. Their current "resolutions" were not final, but instead recognize a process of continual growth and change. Jessie, for instance, explained that she is still trying to figure out a Biblical interpretation of transsexual identity that makes sense to her. For gender identity in particular, participants discussed the continual identity formation and becoming comfortable with themselves. For religious identity, participants mentioned maintaining their core beliefs, personalizing their faith, and not regularly attending church. 


\section{GENDER IDENTITY}

Participants, who range in age from 18 to 53, are still forming their gender identity. Alex explained: "Well, I'm not on one end or the other (of the gender spectrum) and I'm really not sure in terms of my faith how far is appropriate and how far is comfortable to me." As they continue to form and reform their gender identities, participants simultaneously become more and more comfortable with themselves. For instance, Peter explained: "I think I've come to a place in my life where I accept myself for who I am and if others don't like me, for whatever reason, that is their loss." Amy mentioned that she has lived as a female since 2004 and is comfortably "out" in all aspects of her life. Although Jessie is comfortable with living as a woman, she does not have a set plan for if and when she will obtain sex reassignment surgery (though she says that she hopes to do so in the future). Further, she is aware that, as she stated: "The truth of the matter is that people don't want trannies around. They really don't." She went on to say: "I don't care how comfortable you become, you're terrified that somebody is going to out you, or somebody is just going to treat you as a neither." Regarding gender identity, these individuals are unsure what lies ahead, and whether or not they will undergo sex reassignment surgery.

\section{RELIGIOUS IDENTITY}

In addition to continually resolving their gender identity, participants also discussed how they must do the same with their religious identity. First and foremost, participants explained that through everything, they have mostly maintained their core, Christian beliefs. Steve explained that he has held on to the fact that God made him the way his is for a reason and God gave him his gender identity for a reason. Similarly, Alex stated that she always heard growing up that "God made you the way you are and you should appreciate it" and "God loves you the way you are." She went on to say that "It wasn't really connected with gender identity but that's always something I grew up with. You know, it's all about love, but it's also about who you are. So I've been thinking about that a lot." Peter thoughtfully explained how he has managed to maintain his core, Christian beliefs:

I still have the same values and beliefs that I was raised with. I've just had to work out perhaps changing definitions or changing meanings. As I've gotten older and experienced life, I've realized we have to allow grey areas, but, yes, I still have firm belief in the basic tenants of Christianity.

Unlike the other participants, Amy has taken on an identity in addition to her Christian identity: Agnostic. She explained that she still considers herself a Christian but that she is "more liberal" and that she sometimes takes on the 
label of Agnostic. She says of religion: "I have gotten a lot more cynical about religion. I don't really have any use for any of the major denominations. I'm really frustrated by their lack of change on some issues."

In addition to maintaining core beliefs, participants explained that they have personalized many aspects of their faith over time. In describing his religious beliefs, Peter said:

I have kind of a personal religion type of thing. Or is it even "religion"? I don't know if it's even really religion. It's just more of a connection to God in my mind and where every morning I have my quiet time ... religion is for people who are afraid to go to hell and spirituality is for people who have already been there.

The process of resolving conflict between gender identity and religious beliefs allowed Peter to understand that "there is something beyond or besides organized religion" and he now leans more towards a "nondenominational spirituality." Like Peter, Steve has a new understanding of his religious identity. He explained:

I have a better understanding in some ways and in some ways I have no understanding at all. I have a better understanding of how I believe the universe works ... To a certain extent most of those things would still be classified under Christian. You'd be hard pressed to find any church that necessarily fits directly with what I believe but that's fairly normal for a lot of people.

Moving towards individual theology while maintaining core beliefs proved to be important in resolving conflict between gender identity and religious beliefs.

However, all of these individuals discussed the fact that they have not been regularly attending church services or been involved in church activities in some time. Steve said that "the biggest problem" is feeling uncomfortable in church. He explained:

To some extent I would really like to find a church where I'd feel comfortable or even just feel anonymous, like a big cathedral up in New York where thousands of people go in and out, and I could just come in and have my worship experience ... If I could go in as a guy and people thought I was a guy or if I could go in as a girl and people thought I was a girl, then that's fine. But right now I don't really feel like I'd be comfortable in any sort of church because I could be judged by the people around me. I feel like I wouldn't feel welcome. More importantly I feel like all that would distract me from the actual act of worshipping God ... I just don't feel like I'm ever going to really belong. 
Likewise, Jessie explained that his reasoning for not attending church is not because she is uncomfortable with the church, but because "the people would lynch me." Alex presented a similar perspective when she questioned what church members would think if she attended a service in a suit and tie. She does not want people to think she is "misled" or that she is "a bad example." Because of these issues, she feels misunderstood and isolated. She is afraid of losing what she has in the way of support from her church family and so she is too apprehensive to go back to her church. However, she reiterated the fact that her faith will stay with her forever, whether she attends church services or not.

\section{DISCUSSION}

Based on the analysis and results, the following discussion outlines theoretical and practical implications and provides suggestions for future research.

\section{Theoretical Implications}

Participants in this study identified as transgender, transsexual, and gender queer. These participants experienced gender identity development as described by Ross-Gordon (1999), and socialization played a large role in their gender identity. During their socialization, participants were influenced by many of the factors mentioned in Ross-Gordon's model, including behaviors, roles, and clothing observed in their families, communities, and churches. However, the participants in this study did not conform to these socialized expectations. Instead, they experienced, as described by Devor (2004) and Morgan and Stevens (2008), dissonance between their bodies and minds. Most had physically transitioned into the preferred gender, but this transition did not yet include sex reassignment surgery for any of the participants. Finally, participants discussed many of the experiences presented by Tanis (2003), including keeping their dissonance a secret, struggling with their spiritual and religious beliefs, and being depressed, isolated, oppressed, and rejected.

In addition to their gender identifications, participants discussed their spiritual and religious identities. Of the five, two were raised Presbyterian and Baptist, one in the Church of Christ, one Catholic, and one Methodist. Currently, all continue to identify generally with the Christian faith in some way. They identify as Christian, nondenominational Christian, Catholic, both Agnostic and Christian, and as belonging to the Church of Christ. It was often because of their gender identity that many initially questioned church doctrine and further developed their faith. Amy, for example, explained that she was "forced" to question and deal with what her church said because of her 
"gender issues," and that it was her gender identity that initiated her changing religious views. Similar to Fowler's (1981) approach, faith for these individuals seems to provide purpose in their lives. For most participants, even though their beliefs and ideas about faith changed substantially, their core beliefs remained the same throughout their faith development. None currently attend church services, preferring instead a personalized faith where they can be themselves.

Finally, in creating personalized faith and gender identities, these participants are, in essence, queering notions of faith and gender. Their lives not only trouble the binary notion of gender, but also dismiss the idea that someone cannot be simultaneously transgender and Christian. These participants are examples of postmodern identity, and they will continue to grow, develop, and change their multifaceted identities.

\section{Practical Implications}

The information gained from this study can be helpful for many transgender individuals, and counselors can utilize the model of conflict resolution to normalize clients' situations. Furthermore, practitioners can make tentative intervention suggestions to clients based on this model. For instance, individuals may benefit from examining expectations regarding gender in their families, churches, and communities, and from identifying areas of their lives that they would like to change. When applicable, therapists can refer clients to support groups, medical professionals, and specialists.

Taking a macro approach, helping professionals can advocate with the transgender population, especially as the DSM continues to be revised and reconsidered. Advocacy can also occur within faith communities, and practitioners can provide information and assistance to those who desire to become more welcoming. Tanis (2003) explains that welcoming religious communities have:

Genuine hospitality, nondiscrimination policies and attitudes, appropriate and inclusive language, the visible and audible presence of trans people and programs, provision of meaningful rituals to mark changes, outreach to trans groups and individuals, opportunities for the congregation to learn accurately about trans issues, and rest rooms that the gender-variant can access. (p. 122)

\section{Future Research}

This study reports on one of the first scholarly attempts to examine the process by which transgender, transsexual, and gender queer individuals with a Christian upbringing resolve conflict between gender identity and religious beliefs. Future research should attend to the limitations of the study. 
Subsequent studies should also include further investigation into the theory of conflict resolution presented in this article, and researchers should complete wide-scale, quantitative studies in the future to investigate the generalizability of this theory. Additional groups based on gender identity and religious upbringing should be included in such investigations. These populations might include intersex individuals and/or those with a Jewish, Muslim, or other faith upbringing. Finally, researchers should investigate the effectiveness of specific interventions based on this theoretical model of conflict resolution.

\section{REFERENCES}

American Psychiatric Association. (2000). Diagnostic and statistical manual of mental disorders (Rev. 4th ed.). Washington, DC: Author.

American Psychological Association. (2006). Answers to your questions about transgender individuals and gender identity. Retrieved from http://www.apa. org/topics/sexuality/transgender.pdf

Applegate, J. S. (2000). Theory as story: A postmodern tale. Clinical Social Work Journal, 28(2), 141-153.

Bogdan, R. C., \& Biklen, S. K. (2007). Qualitative research for education: An introduction to theories and methods (5th ed.). New York, NY: Allyn and Bacon.

Buchanan, M., Dzelme, K., Harris, D., \& Hecker, L. (2001). Challenges of being simultaneously gay or lesbian and spiritual and/or religious: A narrative perspective. The American Journal of Family Therapy, 29, 435-449.

Burdge, B. J. (2007). Bending gender, ending gender: Theoretical foundations for social work practice with the transgender community. Social Work, 52, $243-250$.

Charmaz, K. (2006). Constructing grounded theory: A practical guide through qualitative analysis. Thousand Oaks, CA: SAGE Publications.

Coady, N. (2001). An overview of theory for direct practice and an artistic, intuitiveinductive approach to practice. In P. Lehmann \& N. Coady (Eds.), Theoretical perspectives for direct social work practice: A generalist-eclectic approach (pp. 27-45). New York, NY: Springer Publishing Company.

Couch, M., Mulcare, H., Pitts, M., Smith, A., \& Mitchell, A. (2008). The religious affiliation of gay, lesbian, bisexual, transgender and intersex Australians: A report from the private lives survey. People and Place, 16(1), 1-11.

Creswell, J. W. (2007). Qualitative inquiry and research design: Choosing among five approaches (2nd ed.). Thousand Oaks, CA: SAGE Publications.

Denny, D., Green, J., \& Cole, S. (2007). Gender variability: Transsexuals, crossdressers, and others. In A. F. Owens \& M. S. Tepper (Eds.), Sexual health (Vol. 4, pp. 153-188). Westport, CT: Praeger.

Deutsch, M., Coleman, P. T., \& Marcus, E. C. (Eds.). (2006). The handbook of conflict resolution: Theory and practice (2nd ed.). San Francisco, CA: Josses-Bass.

Devor, A. H. (2004). Witness and mirroring: A fourteen stage model of transsexual identity formation. Journal of Gay \& Lesbian Psychotherapy, 8(1), 41-67. 
Donnelly, S. (2001). Building a new moral, religious, or spiritual identity: Perspective transformation in lesbian women (Unpublished doctoral dissertation). Texas A \& M University, College Station, TX.

Eldridge, V. L., Mack, L., \& Swank, E. (2006). Explaining comfort with homosexuality in rural America. Journal of Homosexuality, 51(2), 39-56.

Fowler, J. W. (1981). Stages of faith: The psychology of human development and the quest for meaning. San Francisco, CA: Harper \& Row.

Gherovici, P. (2010). Please select your gender: From the invention of hysteria to the democratizing of transgenderism. New York, NY: Routledge.

Glaser, B. G. (2007). Doing formal theory. In A. Bryant \& K. Charmaz (Eds.), The SAGE handbook of grounded theory (pp. 97-113). Thousand Oaks, CA: SAGE Publications.

Halperin, D. (1995). Saint-Foucault. New York, NY: Oxford University Press.

Jagose, A. (1996). Queer theory: An introduction. New York, NY: New York University Press.

Kennedy, J. (2008). The transgender movement. Christianity Today, 52(2), 54-58.

Kidd, J., \& Witten, T. (2008). Understanding spirituality and religiosity in the transgender community: Implications for aging. Journal of Religion, Spirituality E Aging, 20(1/2), 29-62.

Kolakowski, V. S. (1997). Toward a Christian ethical response to transsexual persons. Theology \& Sexuality, 6, 10-31.

Kujawa-Holbrook, S. A., \& Montagno, K. B. (Eds.). (2009). Injustice and the care of souls: Taking oppression seriously in pastoral care. Minneapolis, MN: Fortress Press.

Levy, D. L. (2009). Gay, lesbian, and queer individuals with a Christian upbringing: Exploring the process of resolving conflict between sexual identity and religious beliefs. Dissertation Abstracts International, 69(08), 282A (UMI No. AAT $3326661)$.

Lewis, J. (2009, September 3). Transgender and Christian: Finding identity. Religion Dispatches. Retrieved from http://www.religiondispatches.org/archive/ sexandgender/1803/transgender_and_christian:_finding_identity

Maxwell, J. A. (2005). Qualitative research design: An interactive approach (2nd ed.). Thousand Oaks, CA: SAGE Publications.

Merriam, S. B. (2009). Qualitative research: A guide to design and implementation. San Francisco, CA: Jossey Bass.

Morgan, S. W., \& Stevens, P. E. (2008). Transgender identity development as represented by a group of female-to-male transgendered adults. Issues in Mental Health Nursing, 29, 585-599.

Rodriguez, E. M., \& Ouellette, S. C. (2000). Gay and lesbian Christians: Homosexual and religious identity integration in the members and participants of a gaypositive church. Journal for the Scientific Study of Religion, 39(3), 333-347.

Ross-Gordon, J. M. (1999). Gender development and gendered adult development. New Directions for Adult and Continuing Education, 84, 29-37.

Rudacille, D. (2005). The riddle of gender: Science, activism, and transgender rights. New York, NY: Random House.

Schwartz, S. J., Luyckx, K., \& Vignoles, V. L. (Eds.). (2011). Handbook of identity theory and research. New York, NY: Springer. 
Sheridan, V. (2001). Crossing over: Liberating the transgendered Christian. Cleveland, $\mathrm{OH}$ : The Pilgrim Press.

Stone, K. (2007). "Do not be conformed to this world": Queer reading and the task of the preacher. Theology \& Sexuality: The Journal of the Institute for the Study of Christianity \& Sexuality, 13(2), 153-165.

Swaab, D. F. (2007). Sexual differentiation of the brain and behavior. Clinical Endocrinology \& Metabolism, 21(3), 431-444.

Swartz, P. C. (2003). It's elementary in Appalachia: Helping prospective teachers and their students understand sexuality and gender. Journal of Gay \& Lesbian Issues in Education, 1(1), 51-71.

Talburt, S., \& Steinberg, S. R. (Eds.). (2000). Thinking queer: Sexuality, culture, and education. New York, NY: Peter Lang.

Tanis, J. (2003). Trans-gendered: Theology, ministry, and communities of faith. Cleveland, $\mathrm{OH}$ : The Pilgrim Press.

United States Census Bureau. (2010). Race, combinations of two races, and not Hispanic or Latino: 2010. Retrieved from http://factfinder2.census.gov

Watts, F. (2002). Transsexualism and the church. Theology E Sexuality, 9(1), 63-85.

Wilcox, M. (2002). When Sheila's a lesbian: Religious individualism among lesbian, bisexual, and transgender Christians. Sociology of Religion, 63(4), 497-513. 